УДК 7.05:747.54(477)«20»

DOI

Ольга ШКОЛЬНА,

orcid.org/0000-0002-7245-6010

доктор мистеитвознавства, професор, професор кафедри образотворчого мистеитва Київського університету імені Бориса Грінченка

(Київ, Україна)dushaorchidei@ukr.net

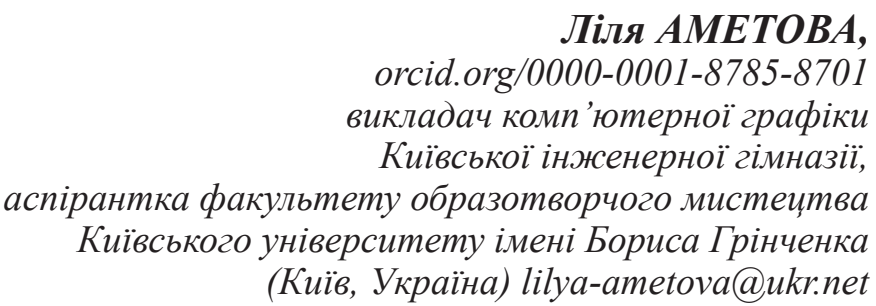

\title{
РЕКЛАМНІ ЛИСТІВКИ С. ГАПЧИНСЬКОЇ ДЛЯ МОЗ УКРАЇНИ ПРОТИ КОРОНАВІРУСУ В ПЕРІОД КАРАНТИНУ
}

\begin{abstract}
Стаття присвячена творчості С. Гапчинської в галузі рекламної листівки упродовж березня-травня 2020 p. Розглянуто серію малюнків для Міністерства охорони здоров'я Украӥни, виконаних художницею з рекламними гаслами та закликами до населення під час пандемії, пов'язаної з коронавірусом. Окреслено жанрову специифіку таких робіт. Охарактеризовано художні та технічні особливості означених творів. Унаочнено серію з вісімнадияти листівок за окресленою тематикою. Розкрито жанрову специфіку рекламних листівок $С$. Гапчинської, які межують із мініплакатом та соиіальною агітаційною листівкою.

Вказано, щзо вже перша з вісімнадияти робіт була створена художницею під егідою Міністерства охорони здоров'я Украӥни 8 квітня через три тижні після початку карантину, иебто 12 березня. На всій серіі в лівому верхньому куті проставлений герб Украӥни та «шапка» МОЗУ, а у лівому нижньому куті зазначено авторство - логотип «Gapchinska» та вказано, щзо художниия представляє «Institute of Cognitive Modeling». Остання названа установа займається соиіальними технологіями, иифрровими технологіями, аналітикою та соиіологічними дослідженнями, міжнародною діяльністю, соиіальною та корпоративною психологією, в тому числі в галузі мистецтвв. Саме ичим спрямуванням характеризуються рекламні листівки Є. Гапчинської під час пандемії.

Визначено послідовність звернення художниці до карантинних закликів та унаочнень у межах вибраної тематики на киталт «Святкую Великдень удома». Виявлений зв'язок творів художнииі зі згаданої серії із сучасним розписом по масках в індустрії моди та муралами з гаслами протидії коронавірусу в різні способи. Перелічені основні твори Є. Гапчинської, щзо підготували звернення до рекламних листівок. Розглянуто складники авторської манери художниці-дизайнерки, щзо виявляється в наведених творах. Представлено аналіз композииї та колористики, а також здійснено формально-стилістичний аналіз вище наведених творів.
\end{abstract}

Ключові слова: мистецтвво проти пандемії 2020 р.

Olga SHKOLNA, orcid.org/0000-0002-7245-6010

Doctor of Fine Arts, Professor, Professor of Fine Arts

of Borys Grinchenko Kyiv University (Kyiv,Ukraine)dushaorchidei@ukr.net

\section{Lilia AMETOVA,} orcid.org/0000-0001-8785-8701, Computer Graphics Teacher of Kyiv Engineering Gymnasium, Graduate Student of the Faculty of Fine Arts of Kyiv Borys Grinchenko University (Kyiv,Ukraine)lilya-ametova@ukr.net 


\section{YE. GAPCHINSKA'S INFORMATIONAL LEAFLETS CREATED DURING THE QUARANTINE PERIOD FOR THE MINISTRY OF PUBLIC HEALTH OF UKRAINE TO PREVENT CORONAVIRUS EXPANSION}

This article is dedicated to Ye. Gapchinska's work in the field of descriptive leaflets created from March to May 2020. Considered is a series of the artist's drawings made for the Ministry of Public Health of Ukraine containing advertising slogans and appeals to the population subjected to the coronavirus pandemic. Such works'genre specificity is identified as well as these works' artistic and technical characteristic features are defined. The presented material series includes eighteen leaflets related to the outlined topic. Revealed is the genre specificity of Ye. Gapchinska's leaflets, identified on the edge on a mini-poster and a revolutionary leaflet.

It is stated that the first of these eighteen works has been created by the artist under the auspices of the Ministry of Public Health of Ukraine already on April 8, three weeks after the quarantine start date, i.e. March 12. In the upper left corner each leaflet of the entire series is marked with the Ukrainian state insignia and the Ministry of Public Health of Ukraine headline, and the leaflets'lower left corner bears the authorship sign, i.e. "Gapchinska" logo with information that the artist represents the "Institute of Cognitive Modeling". That referred to institution deals with social technologies, digital technologies, analytics and sociological research, international activities, social and corporate psychology, including in the field of fine arts. Namely such area designates the focus of Ye. Gapchinska's antipandemic leaflets purposed orientation.

Determined is the sequence following which the artist addressed the quarantine appeals and advices visualization along the chosen theme elaboration, such as "Celebrating Easter at home". A clear relation between the artist's sought series works and the modern fashion industry trend for face masks fabric-painting from one hand and murals containing slogans for counteracting the coronavirus in various ways has been revealed. Listed are the main works of Ye. Gapchinska that constituted a preparatory basis for the appeals represented in the leaflets. The components of designer artist's authentic manner manifested in the studied works being considered, presented is the analysis of that creation composition and coloristics. Also carried out is the aforementioned works formal and stylistic analysis.

Key words: art to combat the 2020 pandemic.

Постановка проблеми. Нині деякі жанри мистецької царини втрачають свою актуальність у соціально спокійні та порівняно стабільні періоди часу. Так, скажімо, не актуалізовані в період миру та спокою такі твори, як рекламна агітаційна листівка із закликами, що генетично пов'язана з мистецтвом плакату. Однак в умовах пандемії художники пригадали добре забуті старі, соціально орієнтовані жанри, які можна виконати вдома, оскільки, скажімо, мурали або стріт-арт реально втілити тільки в умовах вільного пересування, відсутності комендантських чи карантинних годин тощо. У цьому зв'язку варто звернути увагу на останні пошуки Є. Гапчинської, відомої художниці в галузі книжкової графіки, живопису, монументально-декоративного мистецтва та різних галузей дизайну, що в останні три місяці виконала низку соціокультурно орієнтованих творів проти пандемії COVID-19.

Аналіз досліджень. В усі часи художники займали особливе місце в суспільстві як люди, що здатні протистояти війні (революційний плакат і революційна листівка), релігійному насиллю (іконопис та релігійний живопис), соціальній, гендерній нерівності та політичним утискам (стріт-арт, мурал-арт) тощо. Як фахівці, що впливають на формування соціальної свідомості у суспільстві, вони висловлювались у карикатурі, шаржах, памфлетах тощо.

У цьому зв'язку з-поміж останніх публікацій варто згадати статтю кандидата мистецтвознавства
А. В. Будника «Нестандартні види видовищних плакатів 1920-30-х pp. і способи їх донесення до глядача» (Київ, 2015) (Будник, 2015: 21-26), в якій автор намагався переосмислити класичні підходи до аналізу жанрів агітаційного мистецтва в класиків цього напряму 1930-х рр., зокрема, І. Друченка (Друченко, 1930: 1-64) та аналіз досвіду піонерів радянського дизайну С. Хан-Магометова (ХанМагометов, 1995: 1-494). Сучасні взаємозв'язки образів станкового мистецтва окремих напрямів дизайну у творчості $Є$. Гапчинської розглянуто доктором мистецтвознавства, професором О. Школьною у статті «Інтегрування творів образотворчого мистецтва в дизайн середовища на прикладі творчості Свгенії Гапчинської» (Київ, 2018) (Школьна, 2018: 91-106).

Кілька заміток, присвячених муралам у творчості Є. Гапчинської, розглянуто в окремих статтях у всесвітній мережі Інтернет. Зокрема, це публікації «У Дніпрі завершили мурал, створений за мотивами картини Гапчинської» (У Дніпрі, 2019) та «Вуличне мистецтво Чернігова» (Уличное, 2017). Візуальний ряд із рекламних листівок авторства Є. Гапчинської на тему карантину під час пандемії від коронавірусу COVID-19, необхідний для аналізу в цьому дослідженні, представлено на сайтіфайлообміннику Інстанграм під назвою «\#гапчинская Instagram Posts.» (\#гапчинская, 2020).

Мета статті - проаналізувати рекламні листівки Є. Гапчинської із серії проти коронавірусу 
під час пандемії COVID-19, випущені під егідою Міністерства охорони здоров'я України та Інституту когнітивного моделювання, розглянути їх змістову та мистецьку складову частину.

Виклад основного матеріалу. 8 квітня 2020 p. відома українська художниця Євгенія Гапчинська, творчість якої у вітчизняному просторі $є$ надзвичайно популярною (близько 200000 підписників у різних соціальних мережах), під хештегом «\#StopКоронавірус» оприлюднила першу рекламну листівку. Зміст цього твору, як і наступні в цій серії з вісімнадцяти творів, узгоджено 3 MO3 України й Інститутом когнітивного моделювання (ІКМ), зв'язок з ідеями яких унаочнено в їх «шапках» на лівому верхньому і нижньому куті малюнку відповідно.

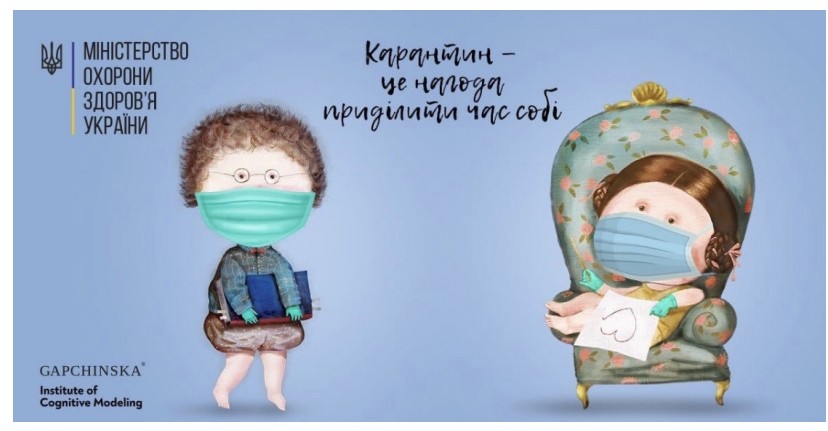

Уже в цій першій листівці під гаслом «Карантин - це нагода приділити час собі» на сіро-блакитному тлі було представлено двоє «фірмових» персонажів Є. Гапчинської - великоголових добродушних дітлахів, одягнених у маски та рукавички, зайнятих своїми творчими справами. При цьому хлопчик зображений із книгою в руках, а дівчинка, що у зручній позі сидить по діагоналі в декоративно вирішеному рококовому кріселку із трояндами в оббивці, вишиває сердечко на прямокутному клаптику тканини на кшталт носовичка чи серветки.

Композицію твору доповнено пояснювальним невеличким підписом, в якому сказано таке: «Доброго ранку, країно! Карантин - це нагода приділити час собі та справам, які відкладали «на потім». Тому не нудьгуйте та займіться саморозвитком, покращенням здоров'я та поставте собі за мету вийти з карантину кращою версією себе! Бережіть себе та будьте здорові!» (\#гапчинская, 2020). По суті, тут художниця дала певну психологічну установку людям, які стикнулися з вимушеним обмеженням простору та пересування i ще до кінця не розуміли, чим себе зайняти. Ця робота, напевне, створювалась трохи раніше, від початку карантину, однак питання узгодження 3 MO3 та IКМ, імовірно, зайняло трохи часу.
Адже наступний твір цієї серії був викладений в інтернет-просторі уже наступного дня.

Так, друга листівка вказаної авторки з означеної серії з гаслом «Піклуйся про літніх людей!» була оприлюднена вже 9 квітня. У ній на тлі дверей у кімнаті із жовтогарячим кольором стін зображено маленького кудрявого хлопчика 3 крилами позаду. Він стоїть у масці на обличчі та біленькому чепурному костюмчику в темненьку цяточку $\mathrm{i}$, як колись тимурівці, зайнятий «ангельською» роботою з охорони і допомоги нужденним. Персонаж тримає паперовий пакунок із продуктами для літніх людей (там визирають яйця, молоко у пляшці, яблучко, салат-трава, капуста броколі тощо). При цьому вміст цієї передачі, схоже, домальований художницею у програмі графічного дизайну й ніби «вмонтований» у загальну композицію. 3 огляду на те, що Є. Гапчинська активно працює в галузі книжкового оформлення, таке технічне вирішення роботи цілком прийнятне в 11 творчості.

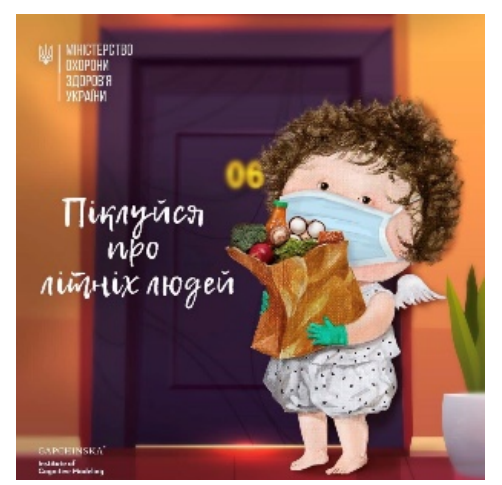

Припис до другої листівки в змісті має чітку інструкцію 3 правил поводження щодо забезпечення провіантом людей старшого віку, завуальовану під форму побажань і ненав'язливих елементів призиву до дій певного характеру (згадаймо добре забуте старе агітаційне мистецтво та агітаційну літературу кінця 1910-х - початку 1930-х pp. (Лунин, 1930: 1-64; Стратен, 1927: 144-164)): «Допомагати одне одному - найвища чеснота. Під час карантину літні люди потребують особливої уваги. Допоможіть їм купити продукти у супермаркеті та залиште пакунки біля дверей. Допоможіть сплатити комунальні послуги онлайн. Спитайте про самопочуття. Частіше дзвоніть літнім родичам. А от особисті зустрічі краще ненадовго відкласти. Адже дотримання дистанції - це і $є$ турбота під час карантину. Станьте для них справжнім янголом» (смайлик із німбом)» (\#гапчинская, 2020).

Окремо варто зазначити в цьому творі контрастність кольорів, зосередження на одній ключовій фігурі, як у плакаті (Андрейканич, 2013: 
21-26), про агітаційну художню мову якого пише А. Андрейканич, та відповідність змісту гасел i приписів зображенню, що як наукову проблему вивчав ще на початку XX ст. I. Друченко (\#гапчинская, 2020).

Третя листівка Є. Гапчинської 3 окресленої серії була присвячена не менш болючому питанню - охороні здоров'я та профілактиці зараження лікарів, які ще на початку карантину часом не мали відповідного одноразового одягу, масок, рукавичок, дезінфекторів, а також в окремих випадках не вірили у страшні наслідки контактування із хворими. Вона була оприлюднена 10 квітня. Тут у центрі композиції під гаслом «Лікарі - сучасні супергерої» на світло-сірому тлі зображена статечна випростана, наче в армії, фігурка кваліфікованого лікаря, здатного надати допомогу, в образі ще одного янгола, одягнена в синій санітарний спецодяг, шапочку на голові, що притримує та накриває волосся, рукавички та маску зеленого кольору.

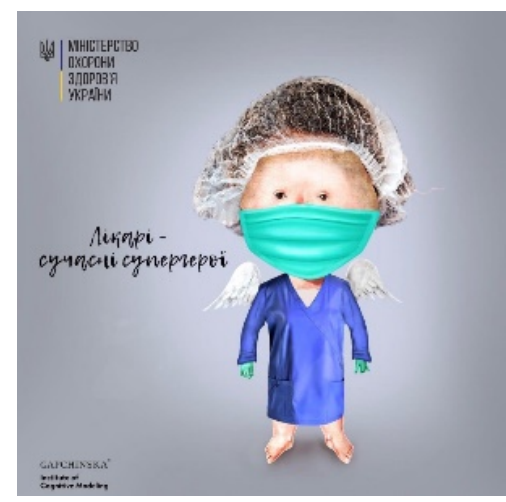

Художниця акцентувала на тому, що працівник сфери медицини в повному «обмундируванні» не має метушитися, а чітко, спокійно, за інструкцією реагувати на вимоги соціуму, а також дотримуватися клятви Гіппократа та не полишати людей у біді, коли від нього залежать життя великої кількості населення. Це був важкий період, коли заразилося багато медиків, i, крім вимушеного закриття таких необхідних лікарень на карантин після раптового зараження персоналу, траплялися випадки «дезертирства» та паніки серед медиків. $€$. Гапчинська тут намагалася в атрактивний спосіб показати гідність цієї професії та нагадати лікарям про їх професійний обов'язок берегти себе і своїх пацієнтів.

Припис до третього твору тут був досить довгим, й, напевне, як і попередні, узгоджувався 3 провідною державною інституцією у сфері регулювання питань охорони здоров'я та приватною установою, де зосереджені фахівці із соціальної адаптації людини у скрутних життєвих умовах та обставинах. Зацитуємо його: «Доброго ранку, країно! (Два сердечка синього та жовтого кольорів - як колір українського прапора). Лікарі щодня рятують тисячі життів. Заради здоров'я пацієнтів ризикують власним. Днями не бачать своїх рідних, а наражаючись на небезпеку, іноді, на жаль хворіють. Але продовжують робити свою справу заради нас iз Вами. Без медиків нам не подолати цього складного шляху. У скрутну годину саме від лікаря може залежати доля кожного із нас. Тому обов'язково підтримуймо їх. Доброю справою, словом подяки чи навіть постом у Фейсбуці. I пам'ятаймо, що залишатись удома, мити руки, тримати дистанцію - це також спосіб підтримки наших лікарів. Будьте дисципліновані та бережіть одне одного! \#StopКоронавірус» (\#гапчинская, 2020).

У цьому приписі було унаочнено шляхетну місію кожного 3 медиків та посил населенню бути максимально обережними, щоб не наражати «рятівників» на небезпеку, після чого пересічні українці стали краще усвідомлювати ці моменти.

Вже наступного дня, 11 квітня 2020 р., С. Гапчинська виклала четверту рекламну листівку соціального змісту. На ній на яскраво-блакитному тлі під гаслом «Турбота - це тримати дистанцію з рідними під час карантину» зображено у двох висвітлених «мандорлах» маленьких, майже анімаційних персонажів у масках: випростаного хлопчика, що загорнувся у смугастий плед із бахромою 3 голови до ніг, наче привид із мультфільму про Карлсона на даху, та на дистанції від ного крихітну дівчинку із довгим біляво-золотавим волоссям штибу «Златовласки», котра тримає у правиці мобільний телефон із заголовком МОЗ України на екрані.

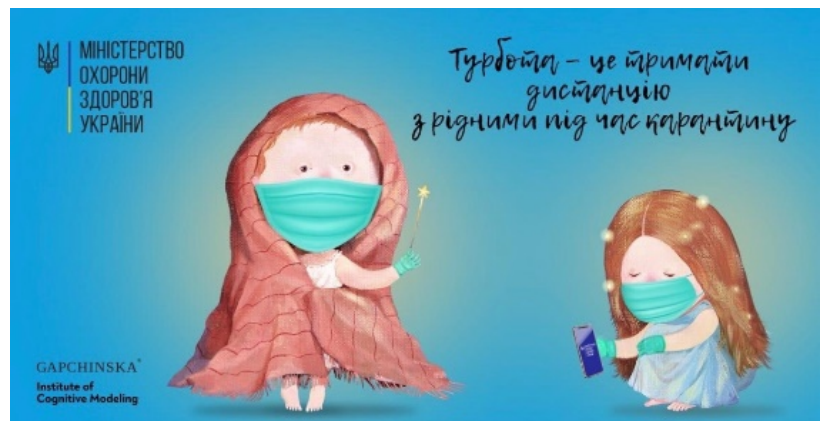

Приписцьогоднягласив: «Доброгоранку,країно! Карантин вніс корективи в життя кожного. Всім нам хочеться скоріше повернутися до звичного життя: гуляти парками, триматися за руки, зустрічатися $з$ друзями та обіймати рідних. Однак небезпека ще не минула. Пік хвороби попереду, а отже, карантин триває. Нам усім варто піклуватися про себе та тих, кого ми любимо! Це означає, що нині 
замість обіймів краще тримати дистанцію, замовте все необхідне онлайн, аби не виходити без крайньої потреби на вулицю. Частіше мийте руки 3 милом. Стежте за самопочуттям. Бережіть себе та своїх близьких. Будьте здорові! \#StopКоронавірус» (\#гапчинская, 2020). Наратив покликаний демонструвати задоволення від перебування в комфортних домашніх умовах, хай і простоволосими та босими, та роз'яснювати правила поведінки в умовах карантину для малечі та родичів.

П'ята листівка, випущена Є. Гапчинською в межах цієї серії 14 квітня 2020 р., мала вже трохи іншу стилістику. Замість простих розваг усередині дому художниця зобразила тут чепурну дівчинку, що зробила рококову високу зачіску із блакитним бантиком на перловому ланцюжку та завитушками на скронях, у стилі мадам де Помпадур, улюбленої фаворитки законодавця французької моди короля Людовіка XVI. Крихітка, крім маски та зелених рукавичок, одягнула піжамку блакитного кольору у дрібнесенькі кружечки i «дефілює» вздовж перил по балкону 3 декоративними колонами та квітучими клумбами у видовжених жардиньєрках. Весь стрій роботи демонструє певне «переодягання» і гру в гламурні забавки, котрі ненасильницьки переорієнтовують людей на лад захисту та перестороги, яка може давати й стильні та великосвітські образи. Гасло тут звучить як «Мої безпечні прогулянки цієї весни».

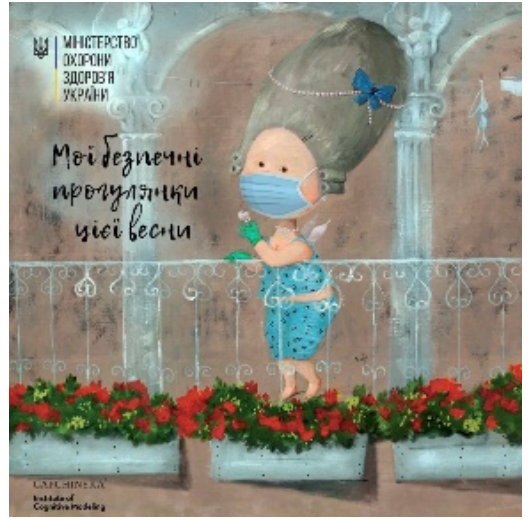

Текст цієї листівки виглядає таким чином: «Доброго ранку, країно! Для багатьох з нас уже стали звичними «прогулянки» на балконі. Може, тим, хто живе у приватному будинку і має власне подвір'я, пощастило трохи більше. Ми жартуємо, плануючи подорожі на кухню чи у вітальню. Зберігайте бадьорий настрій та пам'ятайте, що ми сидимо на карантині не задля карантину, а щоб жити та залишатися здоровими. А поки що подумайте про те, що ви будете робити у перший день після того, як усе це скінчиться! \#StopКоронавірус» (\#гапчинская, 2020). Важливо зазначити, що такі меседжі були б менш зворушливими без добрих картинок $С$. Гапчинської, i, крім того, знайшлося б набагато менше бажаючих повісити тільки текстівку десь у себе на кухні або спальні як пам'ятку. Натомість із візуалізацією казкових образів художниці ці твори набули нового соціокультурного значення.

Наступна, шоста листівка, яка на світло-рожевому тлі під гаслом «Виходжу з дому, коли справді потрібно» демонструє дівчинку з рококовою зачіскою та буклями на скронях, яка під ошатною блакитною парасолькою 3 помпадурівськими бантиками рожево-малинового кольору, у масці та рукавичках, у блакитному стильному комбінезоні на кшталт пісочника 3 декольте, 3 крихітними цятками, на поводку вигулює в гламурному одязі штибу моряцької матроски крихітного мопсика.

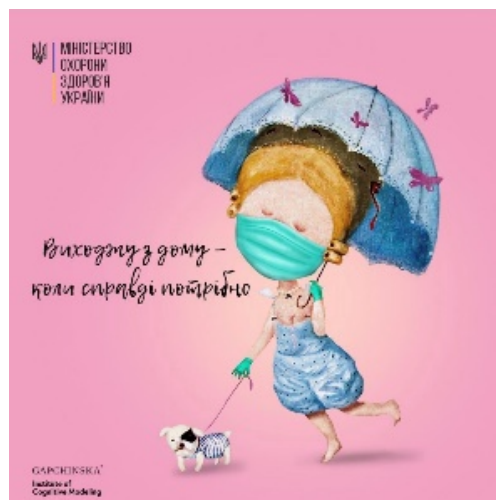

Милу сценку від 15 квітня 2020 р. супроводжує припис: «Доброго ранку, країно» (два звичних вже сердечка). Карантин докорінно змінив наше життя. Тепер навіть похід до магазину - подія, як приємна, так і насторожуюча. Мережею ширяться повідомлення про оренду песиків для «легальних» прогулянок. Дехто бере сусідських «напрокат». Усім власникам чотирилапих улюбленців, які гуляють на вулиці, радимо приділяти особливу увагу гігієні тварин. Ретельно мийте не тільки свої руки, але й лапи тваринки. Прості речі рятують життя. Будьте здорові! \#StopКоронавірус» (\#гапчинская, 2020). Принагідно важливо зазначити, що Є. Гапчинська намагалася максимально зворушливо і щиросердно проілюструвати цю інформацію, в милий спосіб представивши друга людини не як об'єкт торгу чи «оренди».

Сьома листівка від 16 квітня 2020 р. демонструє золотоволосе дівчатко у масці та рукавичках біля сірого столу на тлі жовтенько-персикового тла кімнати за малюванням сердечка. У цій роботі гасло дещо не відповідає змісту супроводжувального напису, та й сердечки вже були введені до попередніх малюнків, тому $з$ точки зору новизни цей твір не $\epsilon$ самим вдалим $з$ означеної серії. Підпис на ньому гласить: «Що я зроблю після закінчення карантину?», хоча візуалізація не дає якогось 
списку чи малюнку плану дій чи хмаринок $з$ їх варіантами як втілення певних ідей та думок.

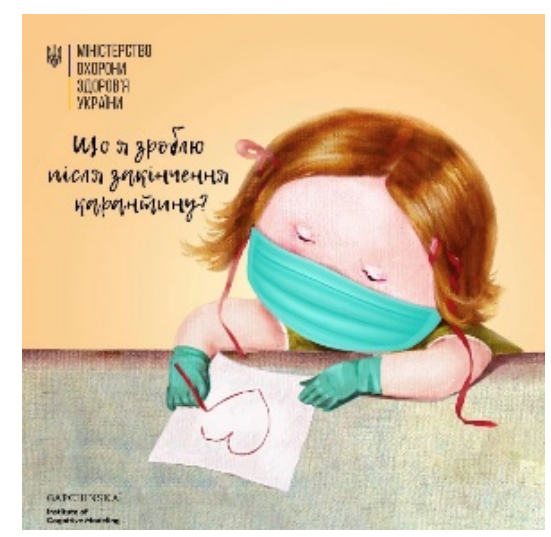

Натомість текст увіщувального характеру дещо не узгоджений зі змістом малюнку, ніби трохи штучно припасованому: «Доброго ранку, країно! (два сердечки). Ми часто відкладали «на потім» плани та бажання, на які бракувало часу. I 3 настанням карантину у багатьох випадках стало зрозуміло, що річ не в часі. На карантині ми дещо переосмислили, частіше почали радіти простим речам. Усвідомили, як цінно купувати запашну каву дорогою на роботу та обіймати друзів. Складаючи плани на «після карантину», пам'ятайте, що все це попереду, а зараз найважливіше - не втрачати пильності, бо безтурботність може коштувати дуже дорого. I наша щоденна мантра: мийте руки, тримайте дистанцію, піклуйтеся про близьких та залишайтеся вдома навіть на свята. Будьте здорові! \#StopКоронавірус» (\#гапчинская, 2020). Тут можна зазначити, що образ майбутнього у цьому творі художниці не дуже вдався, хоча вона могла і не ставити собі це за мету, а зосередитися на думках про планування.

Наступна восьма передвеликодня листівка від 18 квітня 2020 р. представляє маленьку господиню із банним біленьким смугастим рушничком на голові, загорнутим як чалма, у масці та рукавичках. Вона прикрашає великодні яйця на брунатного кольору столі. Постать дівчинки в кораловій маєчці висвітлена світлом «мандорли» на рожевому тлі. Припис цієї композиції звучить у Є. Гапчинської, як віршований слоган: «Той, хто носить масочку, буде їсти пасочку». Зрозуміло, що мотив очищення (може, малювалася робота у чистий четвер) обраний художницею як головний смисловий стрижень роботи. Заради дотримання сангігієнічних засобів профілактики захворюванню, тут унаочнені деталі, пов'язані 3 можливістю з'їсти головні страви Великодня - пасочку та прикрашені яєчка. Нині мисткиня вдалася до традиційного способу ілюстрування бурлесків - українських сцен із народного життя, що мають колоритні примовки, частіше римовані.

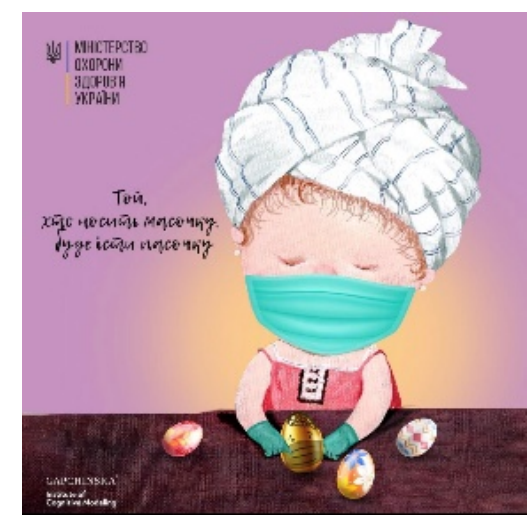

Текст до цієї ілюстрації такий: «(Сонечко) Зовсім трохи залишилося до настання свята Христового Воскресіння. Цього року через світову пандемію ми вимушені змінити багатовікові традиції, і святкування буде дещо іншим. Навіть церемонія сходження благодатного вогню, який $є$ символом світлої звістки та надії, в Срусалимі вперше проходила у тиші, без тисяч вірян з різних куточків світу. Цього року ми особливо чекали Великоднього дива, і воно сталося! Сьогодні багато хто зайнятий останніми приготуваннями до свята. Будь ласка, подбайте про свою безпеку. По можливості замовте «Великодній кошик» онлайн, привітайте рідних телефоном, залиштеся вдома, подивіться церковні служіння по телевізору. Проведіть святкові дні у колі найрідніших. Бережіть себе!» (\#гапчинская, 2020).

Наступною, дев'ятою листівкою від 19 квітня 2020 р. стало великоднє привітанння. Євгенія Гапчинська тут лишилася лаконічною у написі «Залишайтеся на Великдень удома», однак намагалася представити максимально урочисту та святкову композицію. У композиції твору вона скористалася своїми попередніми розробками ілюстрацій до книжок Л. Керолла «Аліса в Країні див» та «Аліса в Задзеркаллі» (обидві 2018 р.), які вона вже раніше застосовувала в декорі пазлів, блокнотів, оформленні календаря за 2019 р. тощо.

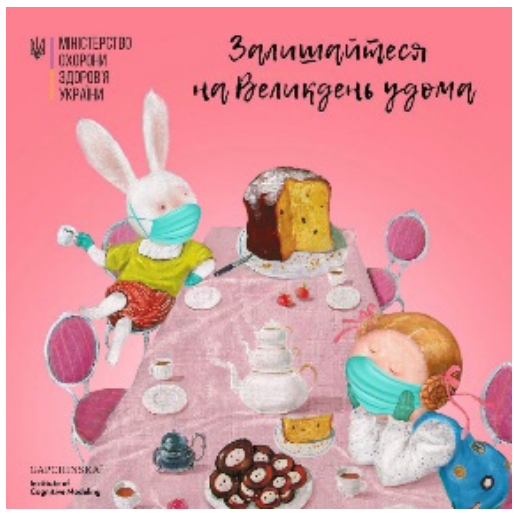


Єдиною суттєвою відмінністю цієї роботи, розробленої для MO3 України у швидкісному режимі, стало застосування рожевого тла і блідорожевої скатертини. У натюрморт на столі, крім фірмових плюшок та трійки чаю (потрійних фарфорових чайників, розташованих один на одному пірамідкою), введена ошатна паска, яку С. Гапчинська розмістила в композиційному центрі роботи, в голові столу, й маленька розрізана пасочка (iіi скибочка) на блюдечку біля Аліси. Маленькі «Аліса» та Кролик чаюють у масках та рукавичках. Святковий настрій художниця підкреслила й ошатними рококовими стільцями 3 рожевими сидушками.

Небагатослівною була і десята листівка другого дня Паски, від 20 квітня 2020 р. У ній художниця зобразила ті самі паски на столі поруч із потрійними білосніжними чайничками із золотавим відведенням на вінцях, виконаними у рококовій стилістиці, а також три золоті яєчка на коричневому столі. Гасло лишилося тим самим, як і у попередній композиції. Тут маленький герой у масці та рукавичках на світло-оливковому тлі мав закріпити уявлення населення про спокійне доїдання пасок у цілковитій самоті як цілком нормальне в умовах карантину та пандемії явище.

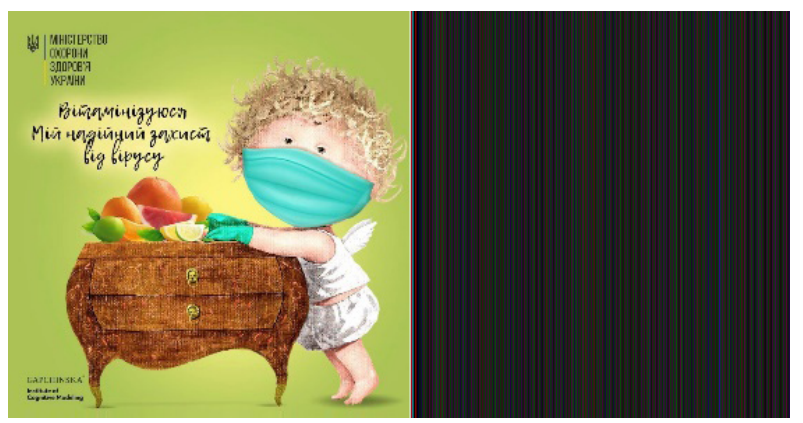

Більш змістовною за пояснювальною частиною стала наступна, одинадцята листівка означеної серії, оприлюднена на третій день по Великодню, 21 квітня 2020 р. Тут під гаслом «Буду дотримуватися карантину - скоріше поїду на море» художниця представила на тому ж ніжнооливковому тлі золотоволосу дівчинку за відпочинком у фіолетово-перлинному кріселку рококової стилістики із високою спинкою, біля якої вбік відходить уявна хмаринка із зображенням вигляду моря й узбережжя як візуалізація мрії, заявленої в девізі-гаслі. Маленька принцеса одягнена у щось середнє між маєчкою та сарафанчиком і задоволено потягується, спершись на смугасту чорно-білу маленьку подушечку, передбачаючи задоволення від побачення 3 морем.

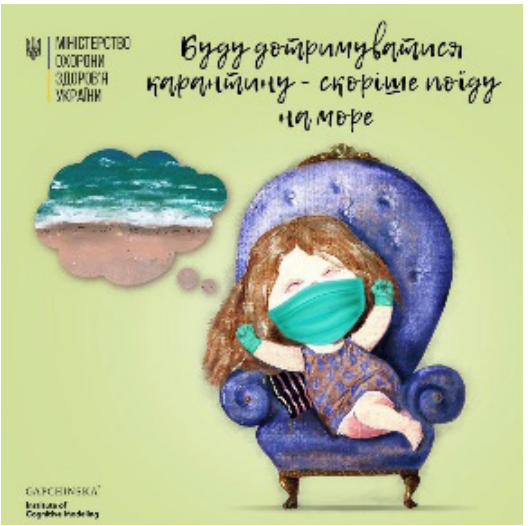

Припис до візії має тут такий зміст: «Доброго ранку, країно! (два сердечка). Фраза, яку за останній місяць ми найчастіше зустрічаємо у мережі, - «Залишайтеся вдома!». Хтось до неї звик і не звертає уваги, а когось вона навіть дратує. Багатьом набридло сидіти вдома, хочеться просто жити і не боятися. Справді, ми всі втомилися. Всі, крім вірусу. Він не знає втоми і не пробачає помилок. Тому, щоб не провокувати спалахів захворюваності і не продовжувати все це, необхідно виконати правила карантину. \#StopКоронавірус» (\#гапчинская, 2020). Можна зазначити, що у цій композиції $Є$. Гапчинській вдалося максимально змістовно у своєму лаконізмі розкрити сутність заявленого гасла, що добре узгоджується із приписом про небезпеки часу, зазвичай відведеного для родинних i дружніх зустрічей. Соціальна реклама тут максимально працює у візуалізації.

Дванадцята листівка від 23 квітня 2020 р. під гаслом «Мої безпечні тренування під час карантину. Зміцнюю імунітет» демонструє хлопчика штибу «Антошки» 3 рудим звивистим волоссям та в масці, одягненого в білу маєчку та червоні штанці й рукавички, що склав руки на грудях, перехрестивши їx. Маленький зображений біля віконечка $з$ блакитними шторами, біля якого стоїть жовтий диван. Поруч із його ногами на підлозі розташовані дві малинові гантелі. Неподалік стоїть жовта чашка на столику. Усе вказує на ранкові заняття.

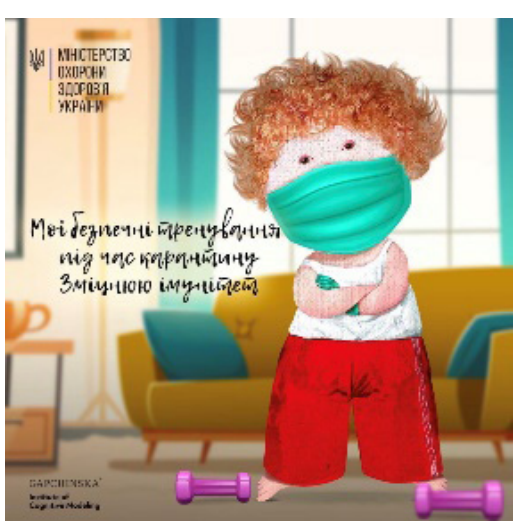


Припис тут має такі рядки: «Доброго ранку, країно! (прапор України). Карантин подовжено. Кількість тих, хто захворів, зростає. Днями ми будемо спостерігати наслідки недотримання режиму під час Великодніх свят. Всі втомилися. Хтось жартує, що від сидіння вдома скоро навіть маски можуть стати замалі. А хтось підтримує фізичну форму тренуваннями. Якщо ви тренуєтесь, тренуйтесь безпечно, дбаючи про себе та оточуючих. Будьте здорові» (\#гапчинская, 2020). Як видно зі змісту текстівки, вона перестає створювати «гламурний» настрій та мало «заряджає» позитивом. Тому, можливо, і С. Гапчинська зобразила персонажа не в дії, а ніби трохи розгубленого, із сумними очима.

Тринадцята листівка від 24 квітня 2020 р. під гаслом «Вітамінізуюся. Мій надійний захист від вірусу» представляє вже не пасивного, а активного малюка в білій білизні, незмінно в масці та рукавичках, та 3 крильцями ззаду. Він тримає прапор України та фрукти (апельсин, лимон, грейпфрут, лайм та яблуко), викладені на рококовий дерев'яний комод. Маленькі очка портретованого висловлюють надію, що все це допоможе зберегти бадьорий дух у бадьорому тілі. Композиція розташована на світло-зеленкуватому тлі. Малюк із вказаними меблями вже раніше обігрувався в станкових творах художниці, тому образ вийшов виразним, а елементи інтер'єру презентабельними, ніби в очікуванні позитивних зрушень.

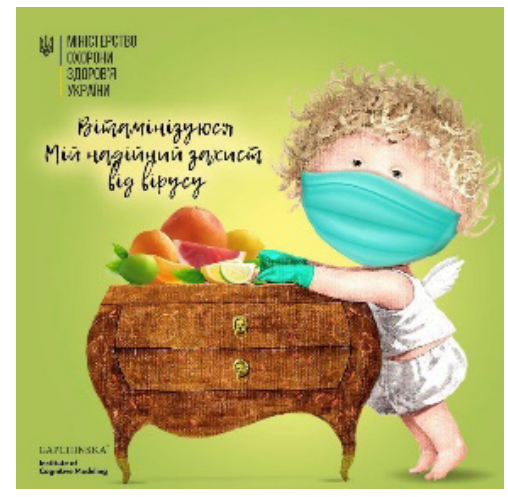

Припис до цієї листівки містить наступний зміст: «Доброго ранку, країно! (прапорець). Весь світ у пошуках вакцини від коронавірусної хвороби. В Україні почалися клінічні випробування препарату, який може зменшити загрозу летальних випадків. Але поки що ліків немає, і хвороба стрімко шириться. Найдієвіший спосіб уберегтися - профілактика та самоізоляція. Зміцнюйте імунітет. Добре висипайтеся. Харчуйтеся збалансовано. Споживайте багато овочів та фруктів. А купуючи їх, дбайте про безпеку та ретельно мийте руки після магазину. Будьте здорові!» (\#гапчинская, 2020). Можна сказати, що ці міркування вдало підсилюються візуалізацією Є. Гапчинської.
На чотирнадцятій листівці від 27 квітня 2020 р. зображено дівчинку із рудим розпущеним волоссям і рожевою трояндою в голові, одягнену у відкриту синю сукню з рожевим трояндовим принтом, маску та рукавички, яка тримає термометр у правій руці. Композиція розташована на рожевому тлі під гаслом «Пильную за самопочуттям щодня». При цьому у приписі йдеться про загальну безпеку, що починається зі стану здоров'я.

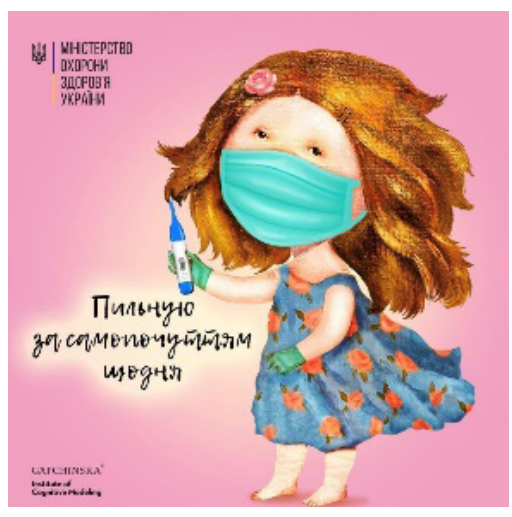

Супроводжуюча текстівка має розлогий текст: «Доброго ранку, країно» (прапорець). На дороги повертаються затори. Вулиці стали не такими безлюдними. Ніби загроза вже минула, ніби вже безпечно. Але наша втома від карантину не означає, що небезпека минула. Стрімке поширення хвороби триває - вже кілька разів ми мали новий антирекорд захворюваності. Стежте за самопочуттям. Дотримуйтесь соціальної дистанції. Тільки від відповідальності кожного 3 нас залежить, наскільки швидко закінчиться карантин. \#StopКоронавірус» (\#гапчинская, 2020). Є. Гапчинська тут змогла унаочнити головну думку у візуалізації.

На п’ятнадцятій листівці від 28 квітня 2020 р. на блакитному тлі з мильними бульбашками зображено рудого хлопчика в маєчці та шортиках, масці та рукавичках, що тримає в руці скляночку з водою. Відповідним $є$ гасло «Підтримую водний баланс, харчуюся корисно». Художниця тут намагалася показати такого собі безтурботного загалом «Антошку», що усвідомлює значення особистого здоров'я.

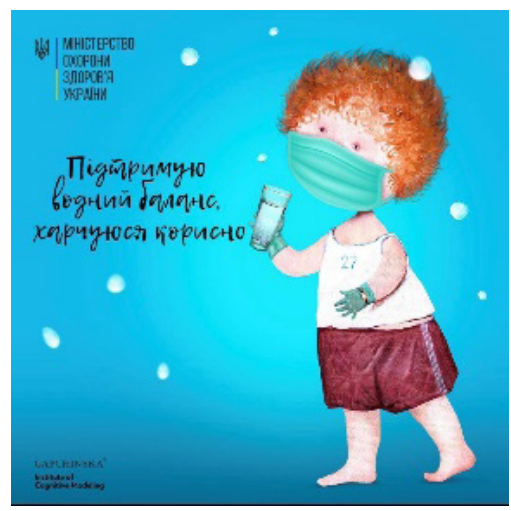


Припис до візії гласить: «Доброго ранку, країно! (прапорець). Часом ми поводимося так, наче маємо супер-силу для захисту від хвороби. Коронавірус може спіткати будь-де. Дорогою на роботу, у магазині чи просто у ліфті. Не частіть 3 алкоголем, підтримуйте водний баланс, харчуйтеся правильно. I до скасування карантину залишайтеся вдома» (\#гапчинская, 2020). Враховуючи, що за деякий час інформація з рекомендацій МO3 почала втомлювати і набридати, С. Гапчинська надалі почала скорочувати свої ілюстрування тез.

Шістнадцята листівка Є. Гапчинською була оприлюднена 29 квітня 2020 р. На ній у передчутті завершення карантину представлено хлопчика в білій хусточці з дрібним принтом у вигляді крижинок на голові, зав'язану в кількох місцях вузликами, аби утворити головний убір кшталту бандани. Малюк одягнений у білу маєчку та коричневі шортики, маску та рукавички й у правій руці тримає зелену гілочку. Його постать розташована на тлі розмитого зображення будиночку та дерев, розтушовка яких наче виконана за допомогою комп'ютерних графічних редакторів. Персонаж зображений із ключиком на шиї, а також годинником на лівій руці. Відчувається план провести травневі вихідні неподалік від власного дачного будинку, подалі від скупчення людей. $€$. Гапчинська тут намагалася показати, що гасло «Проведу травневі свята безпечно» вже не має бути настільки жорстким, щоб зовсім лишити змоги вийти на сонечко і подихати свіжим повітрям, але натякає, що це треба робити в безпечний спосіб.

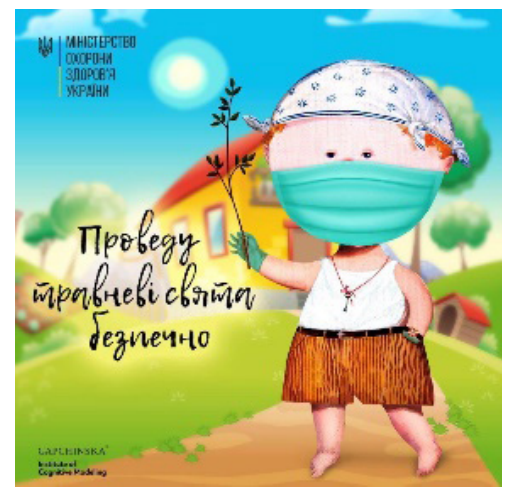

Припис до цієї листівки містить такі рядки: «Доброго ранку, країно! (прапорець). Зазвичай ми святкуємо травневі на природі, збираємося компаніями, смажимо шашлики, подорожуємо або саджаємо картоплю. Ці травневі свята, як і великодні, доведеться провести трохи незвично. Плануючи вихідні, пам'ятайте, що коронавірус ніде не дівся. Люди й досі інфікуються, хворіють і помирають щодня. Будьте обережні \#StopКоронавірус» (\#гапчинская, 2020). Занадто «дорослий» за змістом текст, мало адаптований для ненав'язливих рекомендацій-побажань, тут досить жорстко сформульований. Але $Є$. Гапчинська зосередилась на головному - ненасильницькому спонуканні до убезпечення себе і своїх близьких під час карантину.

Сімнадцята листівка була оприлюднена 3 травня 2020 p. Вона містить зображення дівчинки 3 косичками, загорнутими «бубликами» назад. Крихітка зображена в масці, рукавичках, червоному сарафанчику, білій футболці та паперовій пілотці з газети на голові, у мить, коли взялася за прибирання. Адже в лівій руці вона тримає швабру, а праворуч від неї знаходиться бежеве цеберко з ганчіркою та ще однією рукавичкою. Тло композиції виконано у світло-бузковому кольорі, підлога на кілька тонів темніша. Гасло цієї листівки таке: «Дезинфікую оселю. Роблю вологе прибирання щодня», воно написане із помилкою (після «з» має бути літера «і»), наче його писала дитина. Також тут дещо порушені пропорції в зображенні плечей. Як завжди, портретована показана босоніж, що не дуже узгоджується 3 принципами дезінфекції та прибирання під час пандемії, але робить глядача ніби ближчим до цього маляти, якого хочеться пожаліти.

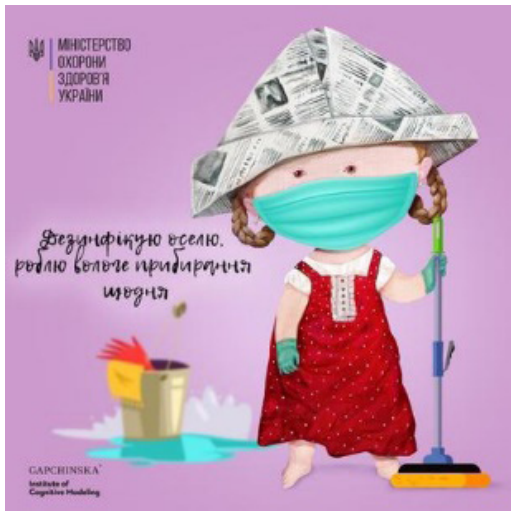

Припис до листівки цього дня: «Доброго ранку, країно» (прапорець). Скоро карантин буде послаблено, тому треба потерпіти ще зовсім трохи. Головне - в останній момент не втратити пильності та гне наробити помилок, що призведуть до негативних наслідків. Будьте обережними та відповідальними! Залишайтеся вдома на травневі свята» (\#гапчинская, 2020). Поступово за цими текстами людей налаштовують на зміни в найближчому часі за наявності терпіння.

Вісімнадцята листівка 3 означеної серії, що була оприлюднена 4 травня 2020 р., вийшла під гаслом «Нарешті час закінчити онлайн-курси». На ній зображено хлопчика зі зкуйовдженим волос- 
сячком, що сидить біля блакитного комп’ютера 3 олівцем у лівій руці та 3 аркушами з блокнотику чи зошиту на столі. Він зображений у висвітленій «мандорлі» на бузковому насиченому тлі, білій сорочечці (охайний і чистенький), масці та рукавичках. Поруч на столі стоїть біла фарфорова чашка, за нею щось штибу канцелярського прибору у вигляді червоного готичного будиночку, біля якого скупчені уявні деревця в формі зеленкуватих кульбабок, що фантазійно наче виростають із поверхні столу. Дещо надуманий антураж наводить на думку, що всі вже скучили за природою, але треба почекати ще трошки, дотримуючись вимог карантину.

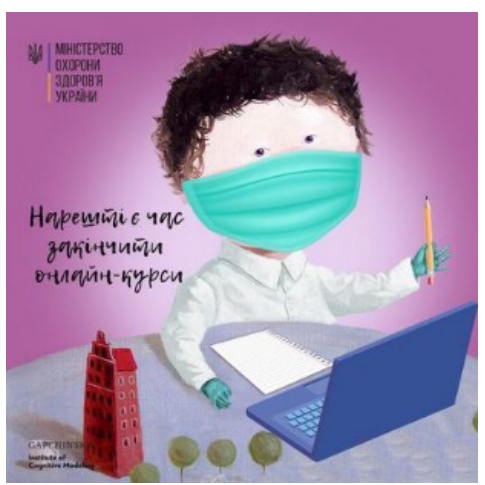

Припис цього малюнку такий: «Доброго ранку, країно! (прапорець). Пом'якшення карантину відбудеться скоро. Та дехто вирішує зробити це вже зараз, на власний розсуд. Нехтує життям та здоров'ям своїм та оточуючих. Замість того, щоб порушувати режим, зробіть все те, на що після карантину не вистачатиме часу. Адже потім будете шкодувати. Будьте здорові!» (\#гапчинская, 2020). Ці рекомендації промовляють до совісті людей, їх соціального обов'язку, що цілком укладається у вимоги до завдань таких листівок. Варто зауважити, що написи, виконані читабельним досить широким шрифтом, зручним для прочитування різними віковими верствами населення. Вони добре тлумачать головні меседжі дня.

Висновки. Загалом можна зазначити, що в листівках із соціальною рекламою, які ілюструють рекомендації Міністерства охорони здоров'я України й Інституту когнітивного моделювання під час карантину через світову пандемію коронавірусу COVID-19, Є. Гапчинська спробувала застосувати прийоми книжкового ілюстратора в сенсі композиційних схем і знайдених образів героїв. У плані агітації, інформативної пропаганди та впливу на велику аудиторію засобами гасел i плакатів вона застосовувала власний досвід праці в галузі мурал-арту (У Дніпрі, 2019; Уличное, 2017) (втілені проекти в Чернігові 2017 р. та Дніпрі 2019 р.) (Baldini, 2017: 91-106; Müller, 2019: 49-57; Petri, 2018: 173-184).

При цьому вона намагалася повернутися до жанрів агітаційної листівки з її лаконічною, але впливовою мовою застережень чи привернення уваги. Досвід праці у рекламному агентстві прислужився художниці в плані вибору головних меседжів із рекомендацій МO3, орієнтованих на соціальні запити широких верств населення. Не всі пошуки однозначно можна назвати вдалими, однак більшість $з$ окреслених творів спонукали людей до зайняття свідомої громадянської позиції, відповідальності за здоров'я своє та своїх близьких. При цьому в максимально стислій формі Є. Гапчинська прагнула донести суть головних рекомендацій MO3 проти коронавірусу COVID-19.

Порівняти сутність виконаних художницею рекламних агітаційних творів нині можна 3 новими віяннями розвитку моди в умовах пандемії, коли дизайнери вводять до ансамблів костюмів, навіть весільних, виразні маски 3 декоративним принтами та захисні елементи одягу для рук штибу різноманітних рукавичок, й розробляють комбінезони (Шанель та інші). Також нині розвивається окремий напрям надактуальних стінописів соціальної спрямованості в межах стріт-арту, в яких окрему увагу райтери приділяють зображенню захисних костюмів та вмасок зокрема. Характерний приклад - мурал на набережній Дніпра співавтора Є. Гапчинської В. Гідевана в Києві 3 левом у захисній масці, робота Бенксі в англійському місті Саутгемптон на підтримку лікарів, а також низка стінописів, присвячених пандемії у США, Варшаві, Нідерландах, Іспанії, Німеччині, Італії, Швеції, Великобританії, Індії, Норвегії, Данії.

\section{СПИСОК ВИКОРИСТАНИХ ДЖЕРЕЛ}

1. Андрейканич А. І. Плакат: його види та жанри. Українська культура: минуле, сучасне, шляхи розвитку. 2013. Вип. 19 (1). С. 121-126.

2. Будник А. В. Нестандартні види видовищних плакатів 1920-30-х pp. і способи їх донесення до глядача. Традииї та новації у вищій архітектурно-художній освіті. 2015. Вип. 3. С. 21-26.

3. \#гапчинская Instagram Posts (08.04.2020 - 11.05.2020). URL: https://gramho.com/explore-hashtag/\%D0\%B3\%D0 \%B0\%D0\%BF\%D1\%87\%D0\%B8\%D0\%BD\%D1\%81\%D0\%BA\%D0\%B0\%D1\%8F (дата звернення: 01.05 .2020 р.).

4. Друченко I. Як робити плякати та гасла. Харків; Київ : Держ. видав. України. 1930. 64 с.: іл. 
5. Лунин Э. Агитационная литература. Литературная энщиклопедия: в 11 т.: т. 1 / Отв. ред. Фриче В. М.; Отв. секретарь Бескин О. М. Москва: Изд-во Ком. Акад. Стб. 45-55, 1930. 768 стб. : ил.

6. Стратен В. В. Творчество городской улицы. Художественный фольклор / Под ред. Ю. М. Соколова. 1927. Вып. II-III. C. 144-164.

7. У Дніпрі завершили мурал, створений за мотивами картини Гапчинської (04.08.2019). URL: https:// dniprograd.org/2019/04/08/u-dnipri-zavershili-mural-stvoreniy-za-motivami-kartini-gapchinskoi_77538 (дата звернення: 06.03.2020 p.).

8. Уличное искусство Чернигова. (2017). URL: https://unexploredcity.com/ru/tour-view/148 (дата звернення: 03.03.2019 p.).

9. Хан-Магомедов С. О. Пионеры советского дизайна. Москва : Галарт, 1995. 494 с.: ил.

10. Школьна О. Інтегрування творів образотворчого мистецтва в дизайн середовища на прикладі творчості Євгенії Гапчинської. Артпростір. 2018. №3. С. 97-100, 129.

11. Baldini A. (2017). Beauty and the Behest: Distinguishing legal judgment and aesthetic judgment in the Context of $21^{\text {st }}$ Century Street Art and Graffiti. Bremen : Elsevier Ltd. P. 91-106. https://doi.org/10.4000/estetica.2161

12. Müller A.-L. (2019). Voices in the city. On the role of arts, artists and urban space for a just city. Rosenberg and Sellier. Volume 91, august. P. 49-57. DOI: 10.1016/j.cities.2018.04.004

13. Petri J. (2018). Touched by a mural: Somatic aspects of urban participation. Lodzkie Towarzystwo Naukowe. Vol. 20. P. 173-184. DOI: $10.26485 / \mathrm{AI} / 2018 / 20 / 11$

\section{REFERENCES}

1. Andrejkanych A. I. Plakat: jogho vydy ta zhanry [Placard: his kinds and genres]. Ukrainian culture: past, present, ways of development. Kyiv, 2013. Vol. 19 (1). Pp. 121-126. [in Ukrainian].

2. Budnyk A. V. Nestandartni vydy vydovyshhnykh plakativ 1920-30-kh rr. i sposoby jikh donesennja do ghljadacha [Non-standard types of spectacle placards of 1920-30th and methods of their report to the spectator]. Traditions and innovations in higher architectural and artistic education, 2015. Vol. 3. Pp. 21-26 [in Ukrainian].

3. \#ghapchynskaja Instagram Posts (08.04.2020 - 11.05.2020). [\#gapchinskaya Instagram Posts] URL: https://gramho. com/explore-hashtag/\%D0\%B3\%D0\%B0\%D0\%BF\%D1\%87\%D0\%B8\%D0\%BD $\%$ D $1 \% 81 \% \mathrm{D} 0 \% \mathrm{BA} \% \mathrm{D} 0 \% \mathrm{~B} 0 \% \mathrm{D} 1 \% 8 \mathrm{~F}$ (data zvernennja: 01.05.2020) [in Ukrainian].

4. Druchenko I. Jak robyty pljakaty ta ghasla. [How to make posters and slogans]. Kharkiv; Kyiv, 1930. 64 p. [in Ukrainian].

5. Lunin E. Agitatcionnaia literatura [Agitation literature]. Literary encyclopedia: in 11 vol.: vol. 1. Moskov, 1930. Pp. 45-55 [in Russian].

6. Straten V. V. Tvorchestvo gorodskoi ulitcy [Creativity of the city street]. Art folklore, 1927ю Vol. II-III. Pp. 144-164 [in Russian].

7. U Dnipri zavershyly mural, stvorenyj za motyvamy kartyny Ghapchynsjkoji. [A mural based on a painting by Gapchynska was completed in the Dnieper]. (04.08.2019). URL: https://dniprograd.org/2019/04/08/u-dnipri-zavershilimural-stvoreniy-za-motivami-kartini-gapchinskoi_77538 (data zvernennja: 06.03.2020 r.). [in Ukrainian].

8. Ulichnoe iskusstvo Chernigova. [Street art of Chernihiv]. (2017). URL: https://unexploredcity.com/ru/tour-view/148 (data zvernennja: 03.03.2019 r.) [in Russian].

9. Khan-Magomedov S. O. (1995). Pionery sovetskogo dizaina [Pioneers of Soviet design]. Moskow: Galart. 494 p.: il. [in Russian].

10. Shkolna O. (2018). Integhruvannja tvoriv obrazotvorchogho mystectva v dyzajn seredovyshha na prykladi tvorchosti Jevgheniji Ghapchynsjkoji [Integrating works of fine art into the design of the environment on the example of the work of Eugenia Gapchinskaya]. Artprostir, Nr 3, pp. 97-100, 129. [in Ukrainian].

11. Baldini A. Beauty and the Behest: Distinguishing legal judgment and aesthetic judgment in the Context of $21^{\text {st }}$ Century Street Art and Graffiti. Bremen: Elsevier Ltd, 2017, pp. 91-106. https://doi.org/10.4000/estetica.2161 [in English].

12. Müller A.-L. Voices in the city. On the role of arts, artists and urban space for a just city. Rosenberg and Sellier, 2019, Vol. 91, august, pp. 49-57. DOI: 10.1016/j.cities.2018.04.004 [in English].

13. Petri J. Touched by a mural: Somatic aspects of urban participation. Lodzkie Towarzystwo Naukowe, 2020, Vol. 20, pp. 173-184. DOI: 10.26485/AI/2018/20/11 [in English]. 